\title{
Talent Management and its Impact on Innovative Work Behaviour among Registered Nurses in Public Hospitals of Malawi
}

\section{George Lewis Dzimbiri}

https://orcid.org/0000-0002-3210-1768

Malawi University of Business and

Applied Sciences

gdzimbiri@ poly.ac.mw
Molefakgotla Alex Molefi

https://orcid.org/0000-0003-2109-2568

North-West University

molefakgotla.Molefi@nwu.ac.za

\section{Abstract}

The Malawi government established and implemented various talent management practices within public hospitals in the country to enhance accessibility, productivity and energy of its health personnel, and to boost the quality of health service delivery. Innovative work behaviours such as the creation, introduction and application of new ideas are key to achieving productivity, accessibility and energy of health personnel. The sure way of achieving innovative work behaviour is through the implementation of talent management. The purpose of this study was to examine the impact of talent management on innovative work behaviour of registered nurses in public hospitals of Malawi. A quantitative research approach was employed, and an adapted Innovative Work Behaviour Questionnaire (IWB) was administered to a convenience sample of $947(\mathrm{~N}=947)$ registered nurses in public hospitals of Malawi. The results of the study showed that talent management practices did not contribute to innovative work behaviour of registered nurses in public hospitals of Malawi. The study, therefore, recommends that management of public hospitals should pay attention to effective talent management practices of healthcare workers, particularly that of nurses in public hospitals. The implication of this study to management in public hospitals is that the results can be used to improve the application of talent management practices at healthcare facilities and help to advance innovative work behaviour of healthcare workers.

\section{UNISA $\approx$}




\section{Dzimbiri, Molefi}

Keywords: innovative work behaviour; public hospitals; registered nurses; talent management

\section{Introduction and Background}

Innovative work behaviour is of central importance in organisations nowadays, as both the pace and force of globalisation and technological advancements necessitate the creation of business value by developing worthwhile ideas into a customer-centric marketable reality. Talent management practices play a crucial role in promoting organisational innovation by increasing the creativity of individual employees (Khaki, Khanzadeh, and Rad 2017). Studies have pointed out the significance of developing innovative behaviour among healthcare workers to ensure that healthcare institutions can provide rapid, reliable, and high-quality patient care (Crowley-Henry, Benson, and Al Ariss 2018; Moloney et al. 2018). Innovative work behaviour, such as the creation, introduction and application of new ideas applied by healthcare workers, has proved to be crucial for promoting patient outcomes and organisational performance (Kamp 2016; Salvador-Ferreira, Fernandez, and Anes 2017).

Additionally, organisations such as hospitals are reliant on the knowledge, creativity, and innovative engagement of their nursing workforces (Abdul-Kareem 2016; Mohammed, Baig, and Gururajan 2019). Innovations in the delivery of healthcare services can result in more convenient, more effective, and less-expensive treatments for today's time-stressed and increasingly empowered health care consumers, and these superior services are primarily provided by nurse practitioners (Pajic et al. 2018). This implies that nurses are required to possess innovative work behaviour to attain organisational objectives because they work closely with patients (Pajic et al. 2018). Further, it is asserted that nurses with innovative work behaviour are expected to swiftly and correctly respond to patients, propose new ideas, and provide new remedies (Kim and Koo 2017). In the same vein, Ki Yah Lei (2018) argues that hospital management must recognise the significance of encouraging creativity and innovative intent among their nurses by using various psychological mechanisms affecting nurses' inclination toward innovation.

Given this, it is worth noting that nurses are critical for organisational innovation, because they play a prominent role in the delivery of healthcare services as they are mandated to provide essential quality services. Therefore, to realise acceptable organisational level innovation, nurses should be well managed through effective talent management (Dias-Silveira et al. 2017). One of the elements of talent management is learning and training management. It must also be emphasised that there is a correlation between learning, training, and innovative work behaviour ( Employees who are involved in various forms of training are more likely to be innovative at their job than those who are not. This implies that talent management stimulates innovative work behaviour in employees and innovative work behaviour has a positive impact on performance improvement (Afsar et al. 2020) 


\section{Talent Management of Registered Nurses in Malawian Public Hospitals}

Malawian nurses play a crucial role in serving a population of over 18 million by providing healthcare services at four levels, namely community, primary, secondary, and tertiary levels (HRH 2018). This is also in accordance with Yildizayvaz, Akyol, and Demiral (2019), who assert that health workers, particularly nurses, play a central role in the management and administration of healthcare for patients. Moreover, in an era of health risks, HIV/AIDS epidemic, stressful work environment, and a turbulent environment to which health facilities such as hospitals are subjected, nurses are still required to provide essential services and tremendous support in peoples' lives (Andrioti et al. 2017; Shulga and Busser 2019). At the same time, they consume a great deal of the country's resources economically (Hariyatia and Safrilb 2017; Nazir et al. 2019). That furthers the necessity to develop talent management strategies that promote their innovative work behaviour.

More so, healthcare facilities in Malawi (especially in the public hospitals) must ensure that they provide the type of services that are appealing to patients. This can be achieved by promoting innovation behaviour among nurses through effective talent management practices. It is worth noting that a skilled and innovative health workforce is central to building a strong health system and ensuring universal coverage of essential health services for all Malawians (HRH 2018), and that a sure way to achieving this objective is through talent management.

\section{Statement of the Research Problem}

Accessibility of quality public healthcare services is one of the key national priority areas for the Malawi government as it impacts the health of the population, which is a necessary factor in the country's endeavour to achieve sustainable economic growth and development (MDGs III 2017-2023). Cognisant of the crucial roles nurses play in the healthcare system, and in a quest to strengthen the quality of healthcare and public health services, the Malawi government implemented various talent management strategies aimed at spurring on the accessibility, productivity and energy of healthcare personnel in the country (HRH 2018; HSSP II 2017-2022). It must be acknowledged that innovative work behaviour such as the creation, introduction and application of new ideas is key to achieving productivity and quality health services (Kim and Koo 2017; Matthew and Stuart 2017), and that a sure way of achieving innovative work behaviour is through the implementation of talent management strategies (Khaki et al. 2017; Woods et al. 2018). Talent management strategies such as talent strategy, talent development, talent deployment, staffing, talent engagement, talent retention, performance management and financial rewards have, subsequently, been implemented by the Malawi government through the Ministry of Health (HRH 2018) in conjunction with numerous bilateral, multi-lateral partners and non-governmental actors (HRH 2018; HSSP II 2017-2022). 


\section{Dzimbiri, Molefi}

However, the nursing profession, particularly in public hospitals, continue to provide poor services to Malawians. Dzimbiri (2018) and Chimenya and Qi (2018) made the same observation and established that there had not been significant improvement in the quality of healthcare services observed in public hospitals since the inception of talent management practices. Among others, the nurses' response to patients has always been slow and often been associated with some degree of negligence (Chimenya and Qi 2018). This decline in patients' support poses a big risk to the patients' lives. Nevertheless, there are many factors that contribute to and cause poor health services, and among the factors are inadequate resources (Dzimbiri 2018) and a lack of innovation.

Unsurprisingly, existing literature reveals a growing and increasing relationship between talent management and innovative behaviour (Asurakkody and Young 2018; Bawuro, Danjuma, and Wajiga 2018; Khaki et al. 2017; Shu-pei 2018). The results of the studies show that talent management positively contributes to innovative work behaviour of employees. Unfortunately, this relationship between talent management and innovative work behaviour, despite being an important area for academic enquiry, has not received much attention from academics and researchers in a Malawian context, particularly the health sector. Moreover, since the establishment and implementation of talent management strategies within the public hospitals, there have not been any studies to unearth how the established talent management practices impact on innovative work behaviour of nurses.

The significances of this study are, therefore, numerous. Firstly, the context is an important contribution to the study because the relationship between talent management and innovative work behaviour was tested within the Malawian context and this has not been done before; hence, more information was obtained to validate the adapted instrument. Secondly, the study is imperative for accountability as it gives an in-depth understanding of nurses' behaviour and the talent management practices that authorities implement. This will, subsequently, help in informing authorities on the best talent management practices to implement. Thirdly, the study is also necessary for advocacy, as it will help to advance and promote best practices for implementing talent management practices in public hospitals.

\section{Literature Review}

\section{Talent Management}

According to Altindağ, Çirak, and Acar (2018), talent management refers to the systematic attraction, identification, development, engagement, retention, and deployment of valuable workforces in the organisation. Wahba (2015) considers talent management as a process that encompasses four variables, namely talent identification, talent development, talent utilisation, and talent retention. A conclusion from the definitions can be made, therefore, that talent management involves systematic 


\section{Dzimbiri, Molefi}

interrelated activities, and that their effective application within the organisation yields a competitive advantage for organisations.

\section{Talent Management Practices}

According to Oladapo (2014), the scope of talent management has five main categories; recruitment, performance management, succession planning, training and development, and retention. He further argues that each of the five elements plays an important role in a talent management framework (Oladapo 2014). On the other hand, the Human Capital Institute (HCI 2011) recognises the scope of talent management as having nine categories. They include talent strategy, talent review process, staffing, talent acquisition, talent engagement, talent development, talent deployment, performance management, and talent retention (HCI 2011). This study adopted the Human Capital Institute's scope of talent management to determine the impact of implementing talent management practices on innovative behaviour of registered nurses in public hospitals of Malawi, because they appear to be more comprehensive and systematic. This implies that in order to achieve innovative work behaviour of employees, all nine elements of talent management should be implemented systematically. These elements are: 1) talent strategy; 2) talent review process; 3) staffing; 4) talent acquisition; 5) talent development; 6) talent deployment; 7) talent engagement; 8) performance management; and 9) talent retention (HCI 2011).

1) Talent strategy: Talent management requires a comprehensive talent strategy. Talent strategy is imperative as it provides direction for the organisation to develop and manage its people both in the short and long term (Susomrith and Amankwaa 2019).

2) Talent review process: This is basically the process of assessing individuals within an organisation to determine high-potential workers and future leaders. The outcome of this exercise helps in succession planning.

3) Staffing: This is the process of attracting applicants with certain skills, abilities and other personal characteristics to job vacancies in an organisation. This helps the organisations to have an adequate level of skills for both the present and future (Susomrith and Amankwaa 2019).

4) Talent acquisition: This the process of acquiring and assimilating the best talent (Van Zyl, Mathafena, and Ras 2017). It is aimed at ensuring the development maintenance of adequate manpower sources. Every organisation, like hospitals, should have a talent acquisition policy to guide the manner in which organisations acquire talent.

5) Talent development: It is the process of subjecting the organisation, its employees and stakeholders to learning in order to achieve and maintain a competitive advantage for the company (Onyango and Kwena 2017). Organisations employ different methods for talent development, such as coaching and mentoring. 


\section{Dzimbiri, Molefi}

6) Talent deployment: This entails placing employees into various sections to make sure that no department/section is overstaffed or understaffed (Tyskbo 2019).

7) Talent engagement: This is the process of allowing employees to be involved fully in the activities of the organisation. These activities include engaging them during target-setting processes, involving them when making decisions, and also delegation (Onyango and Kwena 2017). Employees feel valued and recognised when engaged in organisational activities.

8) Performance management: It entails efforts to improve performance, efficiency, accountability and effectiveness of organisations (SalvadorFerreira et al. 2017). Performance management is the process where employees gain skills, competencies and abilities through planned learning, targets are set for them, followed by monitoring and supervision and finally performance reviews are done (Salvador-Ferreira et al. 2017). Good performers should be rewarded, while, on the other hand, poor performers should be discouraged.

9) Talent retention: It is the process of keeping productive employees within the organisation (Kumar and Bhalla 2019). Organisations these days are prioritising talent retention strategies to avoid the costs related to turnover. Organisations are using different retention strategies to make sure that employees stay. Some of the commonly used retention strategies include, performance-based pay, bonuses, incentives, training and development activities, and so forth (Narayanan 2016; Whysall, Owtram, and Brittain 2019).

There are numerous benefits of talent management. Most importantly, talent management helps an organisation to retain the potential talented workforce to stay in the existing organisation (Olusegun, Akinwale, and James 2020; Tyskbo 2019). Similarly, talent management practices can serve as important instruments to facilitate the achievement of employee outcomes such as retention, commitment, organisational citizenship behaviour, performance, motivation, job satisfaction, and work engagement (Ashe 2018; Burbach, Scroggins, and Royle 2010; Chien and Yick 2016; Ramli et al. 2018). Many studies have also demonstrated that talent management promotes innovative work behaviour of employees (Asurakkody and Young 2018; Bawuro et al. 2018; Khaki et al. 2017; Shu-pei 2018).

Despite the need for and critical roles played by talent management in today's modern organisations, the literature indicates that there are challenges experienced by organisations that have implemented talent management practices. Studies in South Africa reveal that talent management is seldom, if ever, given precedence in organisations, to the extent that it is neither a strategic nor an operational priority for most companies (Barkhuizen et al. 2014; Lesenyeho, Barkhuizen, and Schutte 2018; Theron, Barkhuizen, and Du Plessis 2014). Another related study by Malik, Boyle, and Mitchell (2017) in Botswana on talent management strategies in private higher education institutions (the study was investigating challenges of implementing talent 
management practices in private higher education institutions); the results revealed that talent management strategies were faced with a lack of qualified talent professionals to effectively plan and implement talent management programmes. Similarly, Wahba (2015) conducted a study in Kenya on talent management practices (again the study was aimed at exploring factors affecting the implementation of talent management practices in various companies in Kenya); the results showed that companies lack the necessary resources for talent development investments.

Empirical studies on the relationship between talent management and innovative work behaviour were also conducted in the healthcare sector. The most notable one is that of Khaki et al. (2017) on talent management and innovative behaviour of health professionals in Iran. The results of the study revealed that there was a significant relationship between talent management and innovative work behaviour. Another study by Xerri and Reid (2017) explored the relationship between talent management and innovative work behaviour of nurses in Australian public hospitals. The results showed that talent management practices fostered innovative work behaviour of nurses.

Drawn from the empirical studies, there might be studies having been conducted in the healthcare sector, but the researcher is not aware of them regarding the impact of talent management on innovative work behaviour in the healthcare sector, particularly in a Malawian context. Hence the need to conduct the study in a Malawian context.

\section{Innovative Work Behaviour}

According to Kim and Koo (2017), innovative work behaviour is a person's actions that target realising the origination and intentional outline of new and useful ideas, processes, products, or procedures. Matthew and Stuart (2017) argue it is necessary to maximise the innovative potentials of individuals in every company in this new era of a knowledge-driven economy, because new ideas and initiatives generated by individuals provide organisations with a competitive edge through the enhancement of services and products and the creation of unique products. Thus, practitioners and researchers are expected to provide a conducive environment that encourages individuals to engage in innovative behaviour.

There are many benefits associated with innovative work behaviour among individuals within the organisation. According to Brysiewicz, Hughes, and McCreary (2015), innovative work behaviour is imperative for the long-term existence and success of a company. In this regard, innovative behaviour is crucial for originating new ideas which, in the end, enhance employees' performance. Being one of the productive behaviours in an organisation, innovation behaviour aims at achieving organisational effectiveness.

Many studies have highlighted various factors that influence innovative work behaviour. These, among others, include organisation encouragement, empowerment, resources, and active communication; also, the relationship between group members 


\section{Dzimbiri, Molefi}

affects employees' innovative behaviour (Bos-Nehles et al. 2017; Khachian et al. 2016). Of all the factors highlighted, effective communication and encouragement are considered as the main factors influencing individual innovative work behaviour (Khachian et al. 2016).

Asurakkody and Young (2018) note that organisations can promote innovative behaviour among their employees through the implementation of effective human resources practices. Crucially, there is a need to establish a conducive environment that stimulates learning in organisations. Among other human resource practices, training and development are said to contribute more to innovative behaviour because employees can gain new skills, competencies, and attitudes, thereby enhancing their innovative behaviour. This study, therefore, examined the impact of implementing talent management practices on innovative work behaviour of nurses in a Malawian context. To the best knowledge of the authors, no other studies of a similar nature have been conducted before in Malawi. From the foregoing literature review, the following hypothesis is derived:

H1: There is a positive relationship between talent management and innovative work behaviour.

\section{Purpose of the Study}

The purpose of the study was to examine the impact of talent management on innovative work behaviour of registered nurses in public hospitals of Malawi.

\section{Research Objectives}

The research objective was:

- To investigate participants' perception regarding the effect of implementing talent management strategies on their innovative work behaviour.

\section{Research Methodology}

This is an impact evaluation study, where, after implementing talent management practices, the authors analysed the change in behaviour to a more innovative measure. The innovative behaviours include creation, introduction and application of new ideas. In light of this view, the study adopted a quantitative research design classified as a cross-sectional survey method. According to Saunders, Lewis, and Thornhill (2009), a cross-sectional survey design is well suited to the descriptive and predictive functions associated with correlational research whereby relationships between variables are examined.

A multi-stage cluster sampling technique, as well as a purposive sampling technique, was used to select the public hospitals in various districts of Malawi. According to Saunders et al. (2009) a multi-stage cluster sampling technique involves taking a series 


\section{Dzimbiri, Molefi}

of cluster samples. A purposive sampling technique was used to select the four central hospitals, namely Queen Elizabeth Central hospital, Zomba Central hospital, Kamuzu Central hospital and Mzuzu Central hospital, as they employ larger numbers of registered nurses than other public hospitals (HRH 2018). Furthermore, researching the selected hospitals proved to be cost-effective to the researcher as they were not located in the hard-to-reach areas.

The target population for this study consisted of registered nurses in public hospitals of Malawi. The respondents for each hospital were selected by way of a simple random sampling where every subject had an equal chance of being selected. According to Saunders et al. (2009), random samples are relatively unbiased. Using the Cochran formula (1963), a sample of 947 was drawn from a population of 8334 , at a 95\% confidence level and marginal error of 3\%. 947 questionnaires were administered to respondents over a year (2020) and 580 questionnaires were returned, representing a response rate of $61.2 \%$.

The study used an adapted innovative work behaviour questionnaire in which the items of the questionnaire were adjusted to show the relationship between talent management and innovative work behaviour. The items of the questionnaire were adjusted in such a way that the original meaning of the items was not distorted. Respondents were required to rate each item or statement by indicating how talent management was impacting on innovative work behaviour in the hospitals on a 5-point Likert scale. Essentially, the inputs for the study were talent management practices, namely talent strategy, talent review process, staffing, talent acquisition, talent engagement, talent development, talent deployment, performance management, and talent retention (HCI 2011). The expected output was innovative work behaviour such as creation, introduction and application of new ideas.

Permission to carry out the research was sought from the North-West University in South Africa and directors of selected public hospitals in Malawi through their research ethics committees for their approval, before carrying out the research process. The research proposal had a double review process. Before implementing the research protocol, approval for the research protocol was obtained from the Economic and Management Sciences Research Ethics Committee (EMS-REC) from North-West University in South Africa. Thereafter, another approval was sought from the National Committee Research on Social Science and Humanities (NCRSH) in Malawi. The study was conducted during the year 2019-2020. Data collection took place over a fourmonth period, from April to July 2020. Questionnaires were distributed randomly and manually by giving them to the participants in hand after a comprehensive explanation of the purpose of the research. Respondents were assured that participation in the study was absolutely voluntary and that they were free to discontinue participation at any time. Furthermore, the respondents willingly signed consent forms to participate in the study, but their personal details such as names and organisations were not captured as a way of preserving and guaranteeing anonymity and confidentiality. 


\section{Dzimbiri, Molefi}

Data Analysis

The data were analysed through the use of Stata version-16 software program. The reliability of the measuring instruments was determined using Cronbach's Alpha Coefficients. The validity was confirmed using Confirmatory Factor Analysis (CFA) through Structural Equation Modelling (SEM). A Kaiser-Meyer-Olkin (KMO) test was used in this study to determine the sampling adequacy of data that were to be used for factor analysis. Factor analysis was used to ensure that the variables used to measure a particular concept were measuring the concept intended. The KMO test allowed us to ensure that the data we had were suitable to run a factor analysis. The factorability of the correlation matrix was checked using Bartlett's test of sphericity.

\section{Research Results}

The overall Cronbach's Alpha was found to be greater than 0.9, implying that the items of the innovative work behaviour questionnaire were reliable (Cheung 2013; Perrin 2014). The measures for sampling adequacy for the impact of talent management on innovative work behaviour was 0.927 . The measure was greater than 0.7 , hence items under these two factors were adequate for factor analysis. Furthermore, Bartlett's test of sphericity was carried out and the results indicated that it was also significant $\left(\chi^{2}(36)=3292.958, p<0.01\right)$ hence the items were factorable (Elmi et al. 2017; Gliner, Morgan, and Leech 2011).

The results in table 1 below show that the innovative work behaviour questionnaire was acceptably reliable, and there was no need to drop items to improve reliability. All the item-total correlations were above 0.3 (Cheung 2013; Perrin 2014; Phon-Amnuaisuk, Au and Omar 2016). 
Table 1: Item-total statistics for innovative work behaviour questionnaire

\begin{tabular}{|l|l|l|l|l|}
\hline The items for innovative work behaviour & . & & \\
\hline $\begin{array}{l}\text { Talent management allows me to pay } \\
\text { attention to non-daily work issues in this } \\
\text { hospital }\end{array}$ & 20.80 & 47.997 & .592 & 0.9208 \\
\hline $\begin{array}{l}\text { I am able to wonder how things can be } \\
\text { improved in this hospital because of talent } \\
\text { management }\end{array}$ & 20.56 & 47.306 & .611 & 0.9198 \\
\hline $\begin{array}{l}\text { I am able to search for new working } \\
\text { methods, techniques, or instruments in this } \\
\text { hospital because of talent management }\end{array}$ & 20.62 & 45.293 & .749 & 0.9111 \\
\hline $\begin{array}{l}\text { I am able to generate original solutions to } \\
\text { problems because of talent management }\end{array}$ & 20.61 & 44.868 & .765 & 0.91 \\
\hline $\begin{array}{l}\text { I am able to make others enthusiastic for } \\
\text { innovative ideas in this hospital, thanks to } \\
\text { talent management }\end{array}$ & 20.63 & 44.744 & .743 & 0.9115 \\
\hline $\begin{array}{l}\text { I am able to find new approaches to execute } \\
\text { a task in this hospital because of talent } \\
\text { management }\end{array}$ & 20.61 & 44.814 & .785 & 0.9088 \\
\hline $\begin{array}{l}\text { I am able to convince people to support } \\
\text { innovative ideas in this hospital, thanks to } \\
\text { talent management }\end{array}$ & 20.62 & 45.112 & .751 & 0.911 \\
\hline $\begin{array}{l}\text { I am able to introduce innovative ideas at } \\
\text { work, thanks to talent management }\end{array}$ & 20.69 & 44.325 & .781 & 0.9089 \\
\hline $\begin{array}{l}\text { I am able to contribute to the } \\
\text { implementation of new ideas in this hospital } \\
\text { because of talent management }\end{array}$ & 20.66 & 45.368 & .701 \\
\hline
\end{tabular}

Furthermore, table 2 below shows results on confirmatory factor analysis for innovative work behaviour items. Based on the Kaiser's rule of Eigenvalues (characteristic values) greater than 1, there is only one construct in the innovative behaviour questionnaire. This implies that there was no need to factor the proposed innovative behaviour questionnaire any further (Elmi et al. 2017; Gliner et al. 2011). However, had it been that there were more than one construct in the innovative work behaviour questionnaire with eigenvalues greater than 1 , then there would have been a need to factor further the proposed innovative work behaviour questionnaire. 
Table 2: Confirmatory factor analysis

\begin{tabular}{|l|l|l|l|}
\hline \multirow{4}{*}{ Factor } & \multicolumn{2}{|l|}{ Initial Eigenvalues } & \multicolumn{2}{l|}{} \\
\cline { 2 - 4 } & Total & \% of Variance & Cumulative \% \\
\hline 1 & 5.556 & 61.738 & 61.738 \\
\hline 2 & .838 & 9.314 & 71.052 \\
\hline 3 & .590 & ff6.551 & 77.602 \\
\hline 4 & .457 & 5.076 & 82.678 \\
\hline 5 & .409 & 4.549 & 87.227 \\
\hline 6 & .366 & 4.069 & 91.296 \\
\hline 7 & .296 & 3.283 & 94.579 \\
\hline 8 & .259 & 2.873 & 97.452 \\
\hline 9 & .229 & 2.548 & 100.000 \\
\hline
\end{tabular}

\section{Impact of Talent Management on Innovative Work Behaviour of Registered Nurses in Public Hospitals of Malawi}

The results in figure 1 below show that the implementation of talent management practices did not contribute to innovative work behaviour for the majority of registered nurses. Lack of resources for talent management development investments, lack of qualified talent managers and lack of strategic focus were commonly cited as the contributing factors. Overall, $10.3 \%$ and $37.9 \%$ of participants indicated that they never and rarely used talent management to apply innovative work behaviour respectively. On the other hand, about thirty-six per cent $(35.8 \%)$ of the respondents often used talent management to apply innovative work behaviour and fifteen per cent $(15.1 \%)$ of the participants very often used talent management to apply innovative work behaviour. 


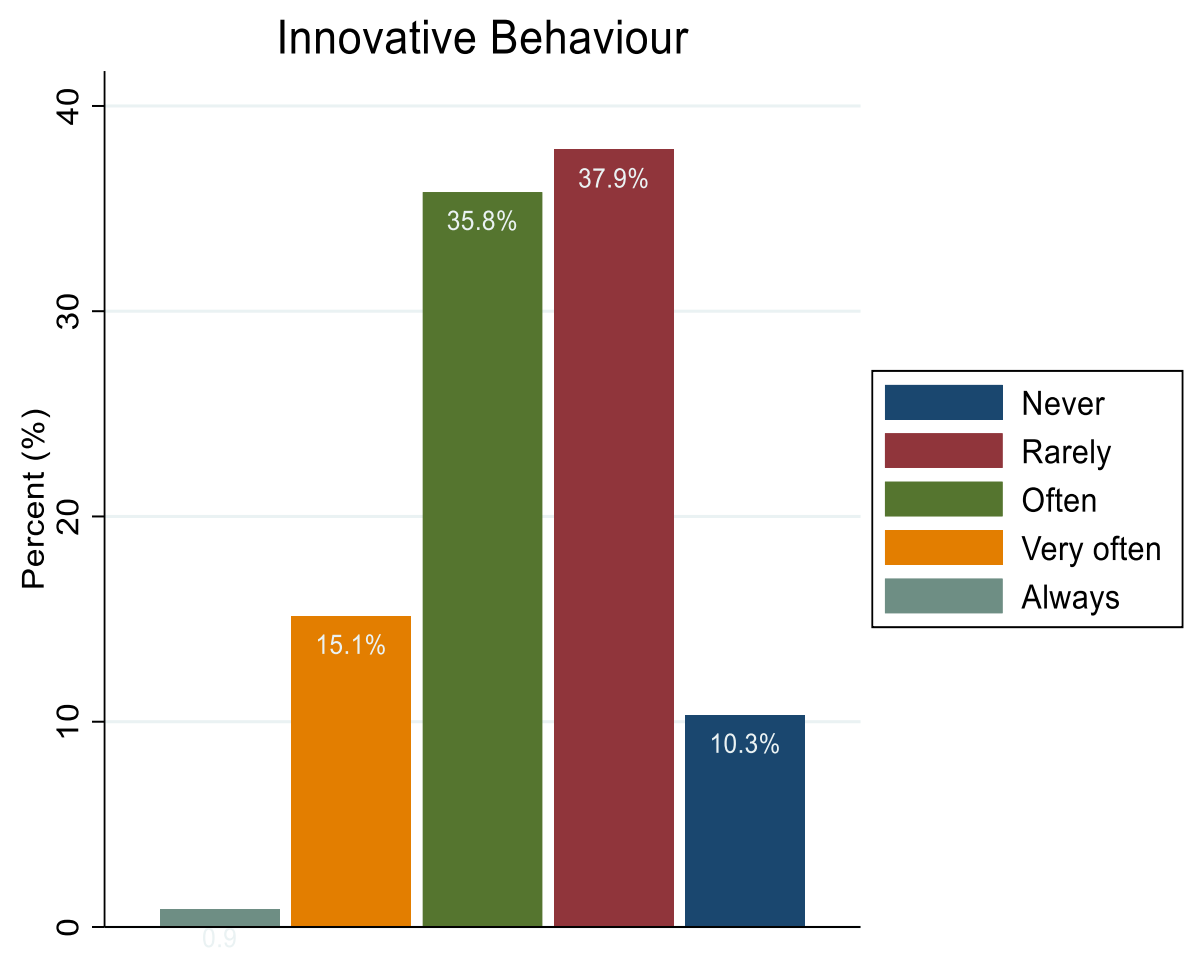

Figure 1: Participants' responses regarding the impact of talent management on innovative work behaviour

\section{Discussion}

The study aimed to examine the impact of talent management on the innovative work behaviour of registered nurses in public hospitals of Malawi. The results are discussed according to the hypothesis set for the study.

H1: There is a positive relationship between talent management and innovative work behaviour.

The results of the study showed that $10.3 \%$ and $37.9 \%$ of participants indicated that they never and rarely use talent management to apply innovative work behaviour respectively. Hence, the study findings were not consistent with the hypothesis and the hypothesis of the study was rejected.

Furthermore, results revealed the problematic nature of implementing talent management practices such as a lack of the necessary resources for talent management development, a lack of qualified talent managers to spearhead the talent management systems, and a lack of strategic focus. The factors affecting proper implementation of 


\section{Dzimbiri, Molefi}

talent management practices highlighted in the study concur with various studies of other countries. In a study by Malik et al. (2017) in Botswana on talent management strategies in private higher education institutions, the results revealed that talent management strategies were faced with a lack of qualified talent professionals to effectively plan and implement talent management programmes. In another study by Wahba (2015) in Kenya on talent management practices, the results showed that companies in Kenya lacked the necessary resources for talent development investments. Furthermore, a study by Barkhuizen et al. (2014) in South Africa found that talent management was poorly applied in the local government institutions in South Africa and lacked strategic focus.

Drawn from the results of the study and other studies highlighted above, it is an indication that factors affecting proper implementation of talent management practices are common across various sectors/industries. The public hospitals of Malawi are experiencing the same challenges to date; no wonder the implementation of talent management practices seems not to contribute to innovative work behaviour among registered nurses.

This study had theoretical and practical contributions. Theoretically, the findings showed that talent management practices did not contribute towards the innovative work behaviour of registered nurses in a Malawian context, particularly in public hospitals. Thus, the study added new knowledge in the field of human resource management regarding the relationship between talent management and innovative work behaviour.

Practically, the study highlighted the problematic nature of implementing talent management practices, such as the lack of resources for talent management development investments, a lack of qualified talent managers to lead the talent management systems, and a lack of strategic focus. In the real sense, when the Malawi government established and implemented the strategies, the expectation was that innovative work behaviour of nurses would improve. The fact that the results of the study demonstrated no improvement in innovative work behaviour among the nurses is a clear indication that the implementation of these strategies was problematic. Furthermore, the results will inform best practices for the public hospital management because they would appreciate the importance of talent management and provide a solution to the challenges affecting the implementation of the strategies, thereby advancing and promoting how talent management strategies should be implemented to support best practices in public hospitals.

\section{Conclusions of the Study}

The study assessed the impact of implementing talent management practices on innovative work behaviour of registered nurses in public hospitals of Malawi. Thus, talent strategy, talent review process, talent development, staffing, talent deployment, performance management, talent engagement and talent retention were implemented 


\section{Dzimbiri, Molefi}

within the public hospitals. Based on the findings, a conclusion was drawn that talent management practices rarely contributed to the innovative work behaviour due to the lack of resources for talent management development investments, a lack of qualified talent managers to lead the talent management systems, and a lack of strategic focus. Importantly, the study was significant in that the relationship between talent management and innovative work behaviour was tested within the Malawian context, a first study in the country. The study also helped to unpack an in-depth understanding of nurses and the talent management practices being implemented. It offered scientific evidence that can be used to hold authorities accountable on how talent management practices should be implemented to support best practices in public hospitals.

\section{Recommendations of the Study}

Talent management practices such as talent development, performance management, talent retention and others play a crucial role in promoting organisational innovation, thereby increasing the level of creativity of individual employees (Asurakkody and Young 2018; Bawuro et al. 2018; Khaki et al. 2017; Shu-pei 2018). Given the evidence that talent management did not contribute to innovative work behaviour of registered nurses in public hospitals, it is strongly recommended that:

- The Malawi government should invest in the health sector, particularly in public hospitals, by allocating more resources such as funding to strengthen the existing talent management strategies.

- Public hospital authorities should make a deliberate effort in providing effective training to talent managers/professionals responsible for planning and implementing talent strategies. This will strengthen the effective implementation of existing strategies, thereby contributing towards the innovative work behaviour of registered nurses.

- Public hospital authorities should make sure that the existing talent management framework is embedded in their overall strategic hospital plans so that it portrays strategic focus. With such integration of a talent management framework within the overall hospital strategic plans, the strategies will always be treated by hospital managers and health workers as very important tools within the public hospitals, hence they would be given the proper attention they deserve.

\section{Limitations of the Study}

This study was cross-sectional and, therefore, faced limits in drawing cause and effect inferences over a long period of time. Further, the study was conducted in public hospitals of Malawi, particularly central hospitals only, and as such the findings cannot be generalised to private and other public hospitals. The other limitation was that the study focused on registered nurses only. The scope of this study left out other healthcare workers such as doctors, hospital administrators, clinicians and dentists. 


\section{Dzimbiri, Molefi}

\section{Acknowledgements}

The authors would like to acknowledge the North-West University EMS-Research Committee and National Health Sciences Research Committee of Malawi for issuing ethical clearance certificates, and the management of the four central hospitals in Malawi for granting permission. We thank all the study respondents for their participation, as well as research assistants for their dedication. We are grateful to the government of Malawi for funding the study through DHRMD.

\section{References}

Abdul-Kareem, A. 2016. "Best Practices for Talent Management: Critical Drivers for Organisational Success and Survival.” European Journal of Business and Management 8.

Afsar, B., B. M. Al-Ghazali, S. Cheema, and F. Javed. 2020. "Cultural Intelligence and Innovative Work Behavior: The Role of Work Engagement and Interpersonal Trust." European Journal of Innovation Management 1460-1060. https://doi.org/10.1108/EJIM01-2020-0008.

Altindağ, E., N. Y. Çirak, and Z. A. Acar. 2018. "Effects of Talent Management Components on the Employee Satisfaction." Journal of Human Resources Management Research 1-20. https://doi.org/10.5171/2018.895618.

Åmo, B. 2018. "Employee Innovation Behaviour in Health Care: The Influence from Management and Colleagues." International Council of Nurses, International Nursing Review 53: 231-237. https://doi.org/10.1111/j.1466-7657.2006.00455.x.

Andrioti, D., A. Skitso, L. E. Karlsson, C. Pandouris, A. Krassias, and G. Charalambou. 2017. "Job Satisfaction of Nurses in Various Clinical Practices." International Journal of Caring Sciences 10 (1): 76-87.

Ashe, L. 2018. “The Importance of Adequate Staffing.” Nursing Management 49 (12): 7. https://doi.org/10.1097/01.

Asurakkody, T. A., and S. S. Young. 2018. "Innovative Behaviour in Nursing Context: A Concept Analysis.” Korean Society of Nursing Science 6 (4): 1317-1976. https://doi.org/10.1016/j.anr.2018.11.003.

Barkhuizen, N., G. Welby-Cook, N. Schutte, and K. Stanz. 2014. "Talent Management and Leadership Reciprocity: The Case of the South African Aviation Industry." Mediterranean Journal of Social Sciences 5. https://doi.org/10.5901/mjss.2014.v5n9p11.

Bawuro, F. A., I. Danjuma, and H. Wajiga. 2018. "Factors Influencing Innovative Behaviour of Teachers in Secondary Schools in the North East of Nigeria." Path of Science 4 (3). https://doi.org/10.22178/pos.32-9.

Bos-Nehles, A., M. Renkema, and M. Janssen. 2017. "HRM and Innovative Work Behaviour. A Systematic Literature Review." Journal of Personal Review 46 (7): 1228-1253. 


\section{Dzimbiri, Molefi}

Brysiewicz, P., T. L. Hughes, and L. L. McCreary 2015. "Promoting Innovation in Global Nursing Practice. "Rwanda Journal Series F: Medicine and Health Science 2 (2): 40-45. https://doi.org/10.4314/rj.v2i2.7F.

Burbach, R., W. A. Scroggins, and T. Royle. 2010. “Talent on Demand?” Personnel Review 39 (4): 414-431. https://doi.org/10.1108/00483481011045399.

Chien, W.-T., and S.-Y. Yick. 2016. "An Investigation of Nurses' Job Satisfaction in a Private Hospital and its Correlates.” The Open Nursing Journal 10 (99-112): 99. https://doi.org/10.2174/1874434601610010099.

Cheung, Y. B. 2013. Statistical Analysis of Human Growth and Development, 1st edition. New York, USA:Chapman and Hall/CRC Press.

Chimenya, A., and B. Qi. 2018. "Investigating the Determinants of Brain Drain of Healthcare Professionals in Developing Countries: The Case of Registered Nurses in Malawi Health Sector." Journal of Human Resources Management Research 1-20. https://core.ac.uk/download/pdf/301021528.pdf.

Crowley-Henry, M., E. T. Benson, and A. Al Ariss. 2018. "Linking Talent Management to Traditional and Boundaryless Career Orientations: Research Propositions and Future Directions." European Management Review 16 (1): 5-19. https://doi.org/10.1111/emre.12304.

Dan, X., S. Xu, J. Liu, R. Hou, Y. Liu, and H. Ma. 2018. "Innovative Behaviour and Career Success: Mediating Roles of Self-efficacy and Colleague Solidarity of Nurses." International Journal of Nursing Science 5 (3): 275-280. https://doi.org/10.1016/j.ijnss.2018.07.003.

Dias-Silveira, C., A. T. Teixeira-de-Bessa, G. Oroski-Paes, M. Andrade, and C. Stipp. 2017. "Nursing Team Management: Factors Associated with Job Satisfaction." Enfermería Global (47): 221-239. https://doi.org/10.6018/eglobal.16.3.249471.

Dzimbiri, G. 2018. "Domestic Politics, Foreign Affairs and Social Economic Factors for Malawi." In Africa Yearbook: Politics, Economy and Society South of the Sahara in 2014, edited by A. Mehler, H. Melber, and K. van Walraven. Boston: Leiden.

Elmi, S., H. Hassankhan, F. Abdollahzadeth, M. A. J. Abadi, J. Scott, and M. Nahamin. 2017. "Validity and Reability of the Persian Practice Environment Scale of Nursing Work Index.” Iranian Journal of Nursing and Midwifery Research 22 (2): 106. https://doi.org/10.4103/1735-9066.205953.

Gliner, J. A., G. A. Morgan, and N. L. Leech. 2011. Research Methods in Applied Settings: An Integrated Approach to Design and Analysis. Routledge. https://doi.org/10.4324/9780203843109. 


\section{Dzimbiri, Molefi}

Hariyatia, U. S., and S. Safrilb. 2017. "The Relationship between Nurses' Job Satisfaction and Continuing Professional Development.” Enfermería Clínica 26: 144-148. https://doi.org/10.1016/S1130-8621(18)30055-X.

Health Sector Strategic Plan 2017-2022. Ministry of Health Report. Lilongwe, Malawi.

Human Capital Institute Africa and Hewitt's Human Capital Consulting (HCI). 2011. "The State of Talent Management: Today's Challenges, Tomorrow's Opportunities." Human Capital Leadership Excellence e-Journal.

Human Resource for Health (HRH). 2018. National Healthcare Quality and Disparities Report. (Report No. 18-0033-EF). Malawi Department of Health and Human Services.

Kamp, E. 2016. "Innovative Work Behaviour: Mapping out the Knowledge Sharing behind it." Master thesis, Utrecht University.

Khaki, I., H. E. Khanzadeh, and A. B. Rad. 2017. "Talent Management and Innovative Behavior Based on the Mediating Role of Organizational Learning." International Letters of Social and Humanistic Sciences 79: 16-28. https://doi.org/10.18052/www.scipress.com/ILSHS.79.16.

Khachian, A., M. Farahani, and H. Hughani. 2016. "Evaluation of Nurses' Professional Behavior and its Relationship with Organizational Culture and Commitment in 2015." International Journal of Medical Research \& Health Sciences (12): 247-252.

Ki Yah Lei, A. B. a. Z. H. 2018. "The Impact of Talent Management on Job Satisfaction: A Study among the Employees of a Travel Agency in Malaysia." Indonesian Journal of Applied Business and Economic Research 1: (1).

Kim, M.-S., and D.-W. Koo. 2017. "Linking LMX, Engagement, Innovative Behavior, and Job Performance in Hotel Employees.” International Journal of Contemporary Hospitality Managemen 29 (12): 3044-3062. https://doi.org/10.1108/IJCHM-06-2016-0319.

Kumar, S. M., and P. Bhalla. 2019. "Stress among Nursing Staff in Hospitals and its Relation with Job Satisfaction, Job Performance and Quality of Nursing Care: A Literature Review." Journal of Nursing and Care 8 (3).

Malik, A., B. Boyle, and R. Mitchell. 2017. "Contextual Ambidexterity and Innovation in Healthcare in India: The Role of HRM.” Personnel Review 46 (7): 1358-1380. https://doi.org/10.1108/PR-06-2017-0194.

Lesenyeho, D. L., N. Barkhuizen, and N. E. Schutte. 2018. "Exploring the Causal Relationship between the Antecedents and Consequences of Talent Management for early Career Academics in South African Higher Education Institutions." SA Journal of Human Resource Management. 


\section{Dzimbiri, Molefi}

Matthew, X., and R. Stuart. 2017. "Human Resources and Innovative Behaviour: Improving Nursing Performance.” International Journal of Innovation Management. https://doi.org/10.1142/S1363919618500196.

Mohammed, A. A., A. H. Baig, and R. Gururajan. 2019. "The Effect of Talent Management Processes on Knowledge Creation A Case of Australian Higher Education." Journal of Industry-University Collaboration 1 (3): 132-152. https://doi.org/10.1108/JIUC-05-20190010 .

Moloney, W., D. Gorman, M. Parsons, and G. Cheung. 2018. "How to Keep Registered Nurses Working in New Zealand even as Economic Conditions Improve." Human Resources for Health 16 (45). https://doi.org/10.1186/s12960-018-0312-x.

MGDS 2017-2023. Malawi Growth Development Strategy Report. Lilongwe, Malawi.

MoH 2018. Ministry of Health Draft Health Policy. Lilongwe, Malawi.

Narayanan, A. 2016. "Talent Management and Employee Retention: Implications of Job Embeddedness: A Research Agenda." Journal of Strategic Human Resource Management 5 (2): 34-40.

Nazir, S., A. Shaf, M. M. Atif, W. Qun, and S. M. Abdullah. 2019. “How Organization Justice and Perceived Organizational Support Facilitate Employees' Innovative Behavior at Work.” Employee Relations: The International Journal 41: 1288-1311. https://doi.org/10.1108/ER-01-2017-0007.

Olusegun, E., O. Akinwale, and G. James. 2020. "Work Environment and Job Satisfaction among Nurses in Government Tertiary Hospitals in Nigeria." Rajagiri Management Journal. https://doi.org/10.1108/RAMJ-01-2020-0002.

Oladapo, V. 2014. "The Impact of Talent Management on Retention in Strayer." Journal of Business Studies Quarterly 5 (3).

Onyango, P. O., and R. Kwena. 2017. "Influence of Talent Management on Employee Retention in Public Hospitals in Kenya: A Case of Siaya Country Referral Hospital." The Strategic Journal of Business and Change Management 4 (2).

Pajic, S., Á. Keszler, G. Kismihók, S. Y. Mol, and D. N. den Hartog. 2018. "Antecedents and Outcomes of Hungarian Nurses' Career Adaptability." International Journal of Manpower 39 (8): 1096-1114. https://doi.org/10.1108/IJM-10-2018-0334.

Perrin, K. K. M. 2014. "Principles of Evaluation and Research for Health Care Programs." Jones \& Bartlett Publisher.

Phon-Amnuaisuk, S., T. W. Au, and S. Omar. 2016. "Computational Intelligence in Information Systems.” Proceedings of the Computational Intelligence in Information Systems Conference (CIIS 2016) (Vol. 532). Springer. 


\section{Dzimbiri, Molefi}

Ramli, A. A., A. Isa, N. L. Baharin, and H. I. Ibrahim. 2018. "The Role of Talent Management in the Relationships between Employee Engagement: A Study of GLCs." MATEC Web of Conferences 150: 1-6. https://doi.org/10.1051/matecconf/201815005060.

Salvador-Ferreira, C. A., F. R. Fernandez, E. M. G. J. Anes. 2017. "Job Satisfaction of Nurses Working in Hospital Units of Northern Portugal.” Revista de Enfermagem Referência 109118. https://doi.org/10.12707/RIV17043.

Saunders, M., P. Lewis, and A. Thornhill. 2009. "Research Methods for Business Students." In Research Methods for Business Students, 128-171, edited by Mark N. K. Saunders, Philip Lewis, Adrian Thornhill, and Alex Bristow. Pearson Education.

Shu-pei, T. 2018. "Innovative Behaviour of Knowledge Workers and Social Exchange Attributes of financial Incentive: Implications for Knowledge Management." Journal of knowledge management 22: 1712-1735. https://doi.org/10.1108/JKM-07-2017-0293.

Shulga, L. V., and J. A. Busser. 2019. “Talent Management Meta Review: A Validity Network Schema Approach.” International Journal of Contemporary Hospitality Management 31 (10): 3943-3969. https://doi.org/10.1108/IJCHM-10-2018-0876.

Susomrith, P., and A. Amankwaa. 2019. "Relationship between Job Embeddedness and Innovative Work Behaviour.” Management Decision 58 (5): 864-878. https://doi.org/10.1108/MD-11-2018-1232.

Theron, M., N. Barkhuizen, and Y. du Plessis, Y. 2014. "Managing the Academic Talent Void: Investigating Factors in Academic Turnover and Retention in South Africa." SA Journal of Industrial Psychology/SA Tydskrif vir Bedryfsielkunde 40 (1): 14-27. http://dx.doi.org/10.4102/sajip.v40i1.1117.

Tyskbo, D. 2019. “Talent Management in a Swedish Public Hospital.” Personnel Review 48 (6): 1611-1633. https://doi.org/10.1108/PR-05-2018-0158.

Van Zyl, E. S., R. B. Mathafena, and J. Ras. 2017. "The Development of a Talent Management Framework for the Private Sector.” SA Journal of Human Resource Management 15: 1-19. https://doi.org/10.4102/sajhrm.v15i0.820.

Wahba, M. 2015. "Talent Management Practices Effect on Employee Engagement: Applied in Logistics Sector in Egypt." Business Research Conference.

Whysall, Z., M. Owtram, and S. Brittain. 2019. "The New Talent Management Challenges of Industry 4.0." Journal of Management Development 38 (2): 118-129. https://doi.org/10.1108/JMD-06-2018-0181.

Woods, S. A., M. J. Mustafa, N. Anderson, and B. Sayer. 2018. "Innovative Work Behavior and Personality Traits: Examining the Moderating Effects of Organizational Tenure." Journal of Managerial Psychology 33: 29-42. https://doi.org/10.1108/JMP-01-2017-0016. 


\section{Dzimbiri, Molefi}

Xerri, M., and S. Reid. 2017. "Human Resources and Innovative Behaviour: Improving Nursing Performance." International Journal of Innovation Management 4 (3):37-43.

Yildizayvaz, M., Y. E. Akyol, and M. Demiral. 2019. "Innovation in Nursing and Innovative Attitudes of Nurses." International Health Administration and Education 5 (2): 52-59. 